\title{
力覚提示機能を有するWWW上に構築された 仮想環境操作システム
}

\author{
市 毛 由希子*1 比留川 博 久*2 高 瀬 國 克*3
}

\section{A Virtual-Model Manipulation System using a Force-Feedback Six-Degrees-of-Freedom Manipulator-on the WWW}

\author{
Yukiko Ichige*1 $^{*}$ Hirohisa Hirukawa ${ }^{* 2}$ and Kunikatsu Takase*3
}

\begin{abstract}
A virtual model-manipulation system - aimed at off-line teleoperation teaching-has been developed on the World Wide Web. To give a feeling to the virtual model manipulation, the system is equipped with a force-display function as well as a virtual display. To realize this feeling, a high-speed contact-motion simulator enables the computation of constrained motion in the virtual environment. In addition, a firm force reaction is produced by using a sixdegrees-of-freedom position-controlled manipulator with force feedback as a master arm. This manipulation system is intended to be used by anybody, anywhere, at any time freely. It uses standard modules (such as Web browsers for GUIs, VRML for graphics, and Java applet) and a position-controlled manipulator for model handling. Consequently, the developed system can be utilized anytime from anywhere equipped with the master arm. A prototype system was developed and virtual model manipulation was carried out successfully in two environment: a simple block world and a complex room environment. The manipulation system was experimentally tested, and it was shown that the new system can effectively manipulate a virual model.
\end{abstract}

Key Words: WWW, Networked Robotics, Force Feedback, Virtual Reality

1.はじめに

ロボットの遠隔操作システムの研究が急速に進められている なか，公衆回線を用いることで特別な配線を必要としないシス テムの開発がなされている，さらに，いつでもどこでも誰でも 操作できるという利点から，Web ブラウザ上に遠隔操作システ ムを構築することが提案されている [1] [2].

Web ブラウザを GUI として用いたロボットシステムの先駆 的な研究として, USCの Mercury Project [3] があげられ，移 動ロボットの操作を行う研究 [4]〜 [6] や, マニピュレータに絵 を描かせる研究 [7] 等も行われている.これらロボットシステム では，オペレータはインターネットを通じてロボットを遠隔操 作し，GUIはHTML をべースに構築されている。これらの研 究ではいずれもオンラインで遠隔操作する方法がとられており, 時間遅れの影響を免れることができず，操作性の向上を図るう

原稿受付 2002 年 4 月 15 日

*1 (株) 日立製作所パーソナルヘルスケアベンチャーカンパニー

*2産業技術総合研究所

*3電気通信大学大学院

${ }^{* 1}$ Personal Healthcare Venture Company, Hitachi.Ltd

*2 National Institute of Advanced Industrial Science and Technology

${ }^{* 3}$ The University of Electro-Communications
えで根本的な制約が科せられている.

一方，ロボットの遠隔操作システムの一つの方式に，オフラ イン遠隔操作システムがある。このシステムでは，まずロボッ トが作業を行う実環境を模擬し，計算機中にこの仮想環境を構 築する. 次にオペレータは仮想環境中のモデルを操作し，ロボッ トが行う操作シーケンスを獲得する．最後に操作シーケンスを 遠隔の実ロボット転送し実行させるシステムである。これは時 間遅れの問題を解決することができる有効な方法である。しか し仮想環境中での操作シーケンスの獲得法と，それを実ロボッ トシステムへ転送し実行させる方法はともにまだ確立されてい ない.

以上を背景とし, 本研究では Web ブラウザを GUI として用 いた，オフライン遠隔操作システムを取り扱う。その中で, 仮 想環境操作システムに焦点を絞り，Web ブラウザを GUI とし て用い，臨場感豊かに仮想環境を操作するための方法について 論じる.

人間が手や足で物体を扱うときは，視覚だけでなく力覚も大 きな役割を果たす，仮想環境を操作する場合も同様であり，臨 場感あふれる良好な操作性を得るには，視覚と力覚に訴える情 報提示が重要である，具体的には，マウスとグラフィック表示 を用いた視覚中心の操作では十分でなく，仮想環境中の物体に 生じる物理的な干涉状態を模擬し，その際の力感覚を運動指示 
デバイスを介してオペレータに提示することが必要である。こ のような力感覚の提示は, 一方的に位置を入力する従来タイプ の仮想環境操作方法との対比から力覚提示と呼ばれ, 各方面で 研究が行われている.

福井らおよび木野らは, オペレータが与えたカベクトルを, 変 位ベクトルに変換して運動指示デバイスに返すことで物体を操作 し，干渉時に接触面の接線方向成分のみを返すことで, 仮想物体 上の衝突と表面なぞり動作を実現する方法を提案した [8] [9]. 木 南らは, マスターアームの機械的な摩擦を利用することで接触状 態を提示する手法に拘束力を導入した方式を提案している [10]. 吉川らは “インピーダンス提示”という概念を提示し, 仮想物 体の表面摩擦を考慮した力覚提示方式を行っており [11], さら に並列バネ駆動方式を用いて，物体の弾性係数を向上させる方 式も提案している [12]. 坂口らは, 入出力デバイスとしてサー ボモー夕等を利用せず，電場によって見掛け上の粘性が変化す る流体を用いたアクチュエータを利用し, 力覚提示システムを 開発している [13].

本研究では, 福井らおよび木野らの方法を一般化し, 仮想環 境の操作における汎用的な力覚提示の方法を与える. 仮想環境 は，標準的な幾何モデル記述用ファイルフォーマットで構築す る. そして本方式に基づき視覚提示と力覚提示を可能とする, Web ブラウザを GUI として用いた仮想環境操作システムを開 発する。

本論文では，2 章で仮想環境における力覚提示方式について 述べ，3 章では仮想環境における物体の拘束運動の導出につい て述べる，4章ではシステム構成，5章では実現したシステム での実験例を示し，最後にまとめを述べる。

\section{2. 仮想環境における力覚提示}

仮想環境中の物体を操作するとき, 従来はマウスなどの入力 デバイスを用いグラフィクスで確認しながら, 物体の位置を変 化させた。この方法によると, 物体は任意の場所に位置決めで きるが, 反面, 物体がほかの物体の中にめり込むといった不都 合が生じる。一方, オフライン遠隔操作システムでは, 物体を 机に置いたり物体同士を組み合わせたりといった拘束状態の制 御が不可欠である。 そこでここでは，物体が机にぶつかれば反 力を受け, 机の面に拘束されるという力学的プロセスを模擬し, よりリアルに仮想環境を操作できる方法を検討する。

力覚提示方式には大きく分けて二つの方法がある. 一つはト ルク制御型のマスタデバイス（アーム等）を用い，オペレータ が変位を入力し，それに対し力をオペレータに対して出力する 方法で，ここでは位置主導型力覚提示方式と呼ぶ.もう一つは 位置制御型のマスタデバイスを用い, オペレータが加える力を 計測（入力）し，それに対し位置を変化させる方法で，ここで は力主導型力提示方式と呼ぶ. 本研究ではシャープな（堅い） 拘束感が得られ, 拘束計算によるむだ時間に対する許容度が比 較的大きな力主導型の方法を採用する，さらにこの方法は，標 準的な位置制御型マスタデバイスを用いることができる利点が ある。

本研究では, 汎用的なシステムの構築を目指す，そこで, 仮想 環境は任意の数と形状の多面体から成るものとし, Web ブラウ

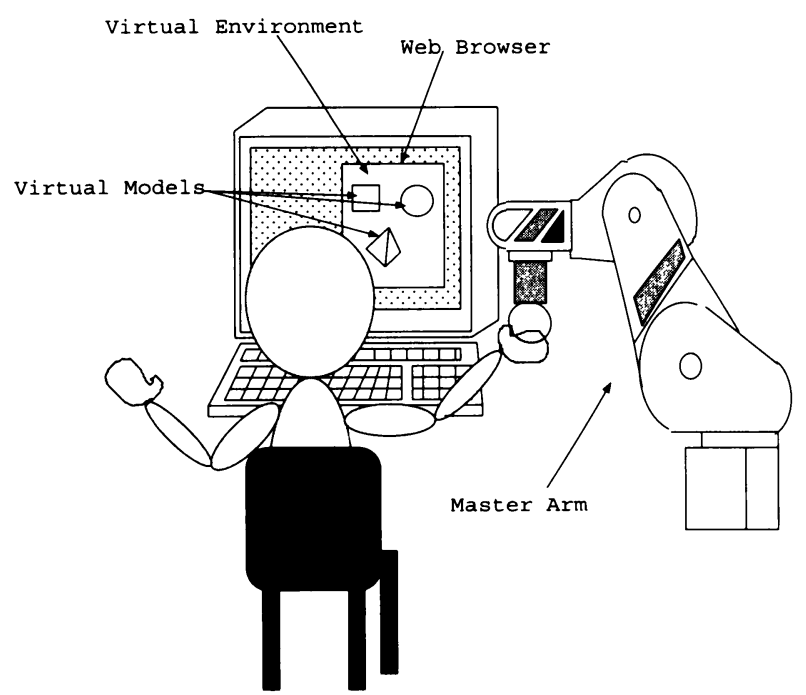

Fig. 1 Image of a force-feedback system with GUI on WWW

ザ上で仮想三次元空間を構築するためのファイルフォーマット である VRML（Virtual Reality Modeling Language）によっ て構築されたモデルを対象とする．作成されたモデルは，仮想 環境のグラフィック表示に用いられると同時に, 力覚提示のた めにも用いられる. 力覚提示のために物体間の接触情報（接触 位置や接触法線等）の検出，および接触拘束下での可動空間の 導出が必要であるため, 上記の幾何モデルを対象とするそれら の汎用アルゴリズムを作成しておく.

力覚提示のための操作・処理の流れは次のようになる (Fig. 1). オペレータはマスタデバイスの先端に取り付けられたグリッパ を握り，グラフィクス表示された仮想環境を見ながら，物体に 対して任意の方向（位置·姿勢 6 自由度）に力を加える. 物体 が自由空間にあるときは，その力の大きさに比例した速度で物 体を移動させ，同時にマスタデバイスも同じ方向に移動させる． 物体が環境と接触しているときは, 力による動作指示ベクトル は可動成分と拘束成分に分解され, 可動成分のみが実行される. これらが実時間で処理されるため, 自由状態から物体が机にぶ つかり，その後机の面をなぞるように進むといった操作を，あ たかも実環境を操作するようにシームレスに行うことができる. 仮想環境中の力覚提示のための, 物体間における接触情報の 検出, 接触拘束下での可動空間の導出を行うソフトウエアは, 干涉判定ソフトウエアである RAPID (Robust and Accurate Polygon Interference Detection) [15] を一部改造し, 拡張した ものである. 次章で, RAPID, 干涉点情報検出方法, 動作可能 成分導出方法について述べる.

\section{RAPID を利用した仮想物体同士の干渉と可動範囲の 導出}

RAPIDは, UNC(Univ. of North Carolina)のD. Manocha らが開発した，ポリゴン同士の干涉状態を高速に判定するソフ トウエアである，RAPID はポリゴンの集合を内包する直方体 である Bounding Boxを求めた後に，これをTreeで表現した 階層構造にしておきこの Tree 構造を利用して干渉判別を行 
う. RAPID は 10 万ものポリゴンから成るような複雑なポリ ゴン同士のすべての接触を， ロバストかつ高速に判定すること ができる，例えば，可動モデルが 2 万ポリゴン，環境モデルが 9 万 8,000 ポリゴンから構成されるとき, 干渉判定にかかる時 間は $6.9[\mathrm{~ms}$ 程度である (SGI RealityEngine $90 \mathrm{MHz}$ R8000 CPU, 512 MB Memory)。また，RAPID は三角形分割された ポリゴンのみに適応しているため, RAPID にモデルを渡す前 に三角形分割を行う必要がある。

\section{1 三角形同士の干涉点情報検出}

RAPID は，三角形分割したポリゴンを Tree 構造にし干涉 を判定している.しかし，ポリゴンを構成する三角形の干涉す る辺を特定していないため, 物体間の接触情報（干涉点座標や, 干涉点における環境モデルの外向き法線ベクトル）を特定する ことができない，そこでここでは，干渉状態判定と同時に干渉 する辺の情報を得るアルゴリズムを与える．モデルは事前に三 角形分割されていることを前提とする．また，可動モデルと環 境モデルの干渉点情報を検出することは，それぞれを構成する 三角形同士の干渉問題に帰着させることができる.

\section{2 多面体同士の干渉}

次に多面体同士の干涉について述べる。例えばFig. 2 のよう に, 多面体 $\mathrm{A}$, 多面体 $\mathrm{B}$ が接触しているとき, 多面体 $\mathrm{B}$ の面 $\triangle B_{1}$ には，多面体 $\mathrm{A}$ を構成する $\triangle A_{1}, \triangle A_{2}, \triangle A_{3}$ で共通 する頂点 $P_{1}$ が接触している. $\triangle A_{1}$ と $\triangle B_{1}$ の接触, $\triangle A_{2}$ と $\triangle B_{1}$ の接触, $\triangle A_{3}$ と $\triangle B_{1}$ の接触すべてにおいて, 三次元空 間における二つの三角形の干渉問題に置き換えることができる. したがって多面体の境界面を三角形分割させることで，三角形 同士の干渉問題として多面体の干渉を判定することができる.

次にこれを基本として，三角形分割された多面体同士の干涉 を判定する方法について述べる。ここでは，多面体の表面を構 成する三角形間の微小量の食い込みにより, 多面体間の接触を 表現する.

三角形の干渉状態には, 点接触・線接触・面接触が考えられ る。これをさらに場合分けすると以下のようになる。

・点接触には, Fig.3 (a) に示すような一方の頂点が他方の

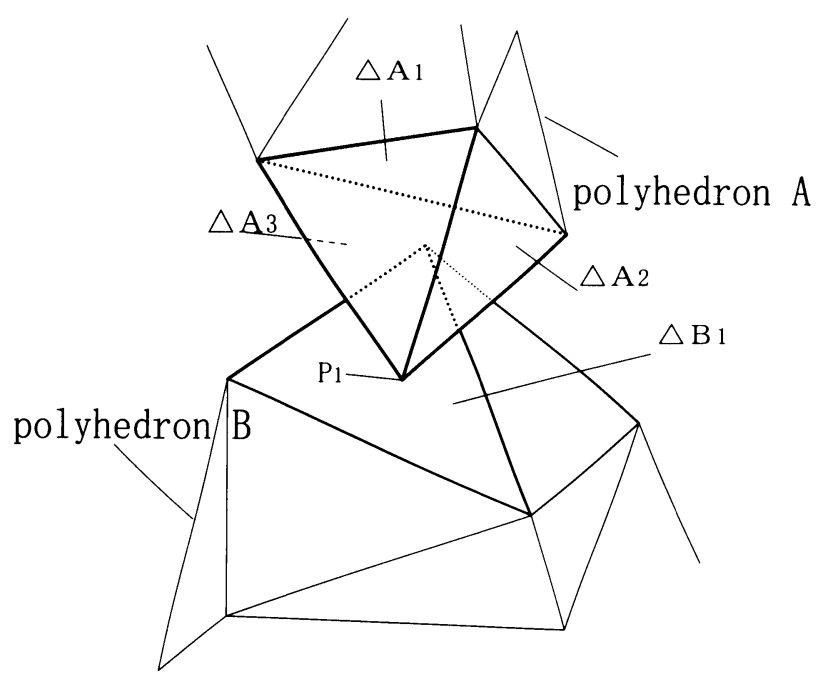

Fig. 2 Collision between polyhedron A and polyhedron B
面に接触している場合と, Fig. 3(b) に示すような両方の稜 が接触している場合がある.

・線接触には, Fig. $3(\mathrm{c})$ （e) に示すような一方の平面に他 方の稜が接触している場合がある。

・面接触は, 当該の三角形同士には干渉がなく, 隣接する三 角形に Fig. 3(a) (e)の干渉が生じる.

文献 [16]によると, 多面体同士の接触による拘束動作は, 代 表的な接触点の位置と, 接触点における環境モデルの外向き法 線ベクトルから求められる. そこで次に, 外向き法線ベクトル の求め方について述べる (Fig.4).ここで, 可動モデルに含ま れる三角形を $\triangle P, \triangle P$ を構成する辺を $e_{i}, e_{i+1}, e_{i+2}$ とし, $\triangle P$ の外向き法線ベクトルを $n$ とする．環境モデルに含まれ る三角形を $\triangle Q, \triangle Q$ を構成する辺を $f_{j}, f_{j+1}, f_{j+2}$ とし, $\triangle Q$ の外向き法線ベクトルを $m$ とすると, 環境モデルの向き 法線ベクトルは以下のようになる.

・Fig.4(a)のように $e_{i}, e_{i+1}$ が $\Delta Q$ に干渉しているときは ベクトル $m$.

• Fig.4(b)のように $f_{j}, f_{j+1}$ が $\triangle P$ に干渉しているとき はベクトル $n$ の逆ベクトル。

- $e_{i}$ と $f_{j}$ が相互に相手の三角形に干涉し, $e_{i} \times f_{j}$ と $e_{i+1}$ のなす角が $-\frac{\pi}{2}$ から $\frac{\pi}{2}\left(\left(e_{i} \times f_{j}\right) \cdot\left(p_{i+2}-p_{i+1}\right)>0\right)$ の ときはこのべクトル $e_{i} \times f_{j}$ を(Fig. 4 (c))，そうでないな らこの逆べクトル (Fig. 4(d)).

次に Fig. 3 に示す三角形同士の接触時に, 接触点における外

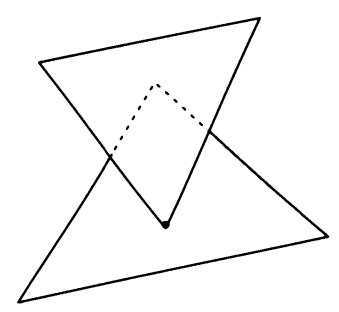

(a)

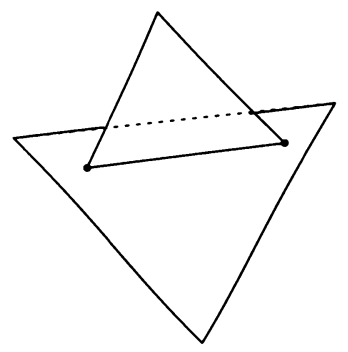

(c)

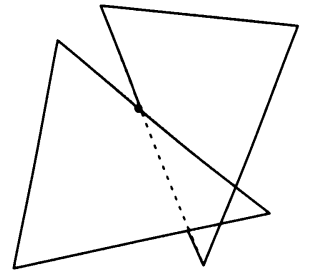

(b)

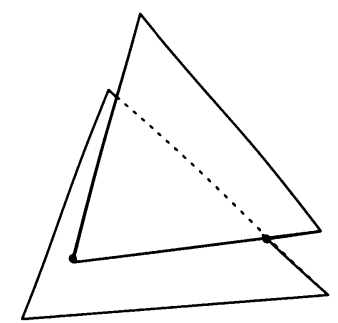

(d)

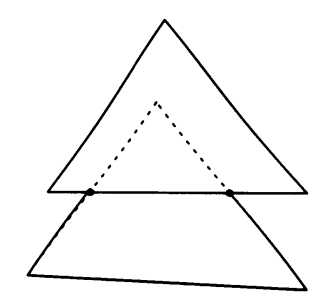

(e)

Fig. 3 Collision types between two triangles 


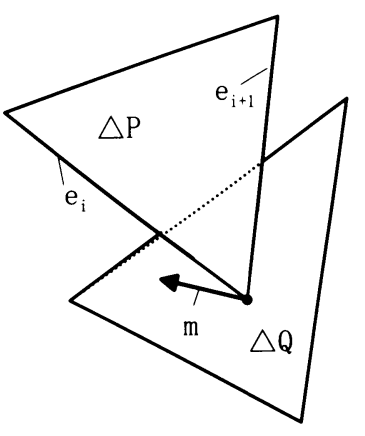

(a)

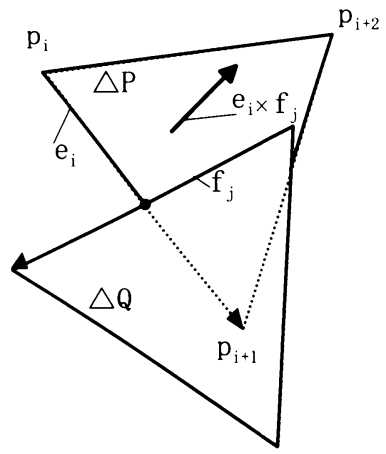

(c)

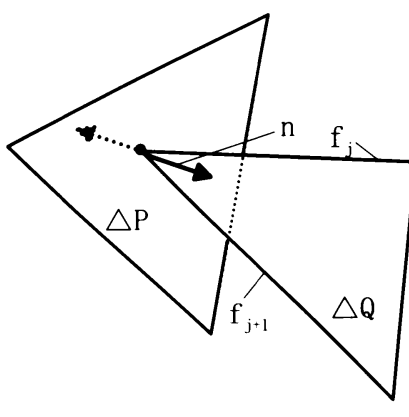

(b)

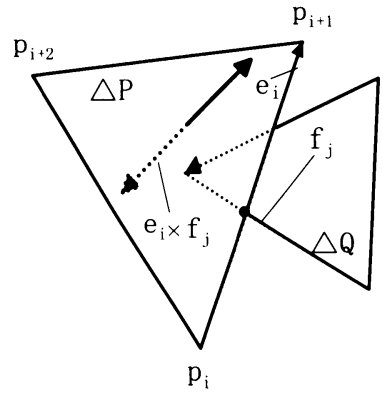

(d)
Fig. 4 A normal vector from the outside of a polyhedron

向き法線ベクトルの求め方を示す.

- Fig. 3 (a) の場合は, Fig. 4 (a) もしくはFig. 4 (b) に相当す る。この頂点を構成する他の三角形の組み合わせでも, 同 じ接触点の位置と外向き法線ベクトルが得られるが, それ らは一つだけ使用すればよい。

- Fig. 3 (b) の場合は, Fig. 4 (c) もしくは Fig. 4(d) に相当 する。これら二つの稜はそれぞれ二つの三角形から構成さ れ，4 種類の組み合わせをチェックすることになるが，すべ てから同じ接触点の位置と法線が得られる.

・Fig. 3 (c) の場合は, 干涉する二つの頂点それぞれにおいて それぞれ接触点の位置と法線べクトルを得る. 二つの頂点 とも Fig. 4(a) または Fig. 4 (b) で対応できる.

- Fig. 3 (d) の場合は, 一つの頂点と一組の稜の交差点で接触 点の位置と法線ベクトルを得るため, Fig. 4 (a), (b) どちら かと, Fig. 4 (c), (d) どちらかの組み合わせで対応できる.

- Fig. 3 (e) の場合は, 二組の稜の交差点で接触点の位置と法 線ベクトルを得るため, Fig. 4 (c) もしくは Fig. 4 (d) で対 応できる。

\section{3 不安定な接触}

多面体間の頂点同士や, 頂点・凸稜間の接触は極めて不安定で あり扱いにくい，そこで本稿では，仮想環境を操作する際，頂 点同士や頂点・凸稜間の距離が一定值 $\varepsilon$ 以下となる動作指示は

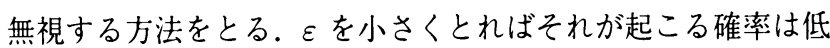
く，仮に起きたとしても，微少な迁回をすることにより不安定 接触を回避する結果となるだけで実際上問題はない。ここで食 い込み量を $\varepsilon$ に対して十分小さくすれば，あらゆる領域で 3.2 節に述べた方法を用いることができる。
部品の最終組み立てなどで生じる頂点同士の接触などの問題 は，頂点や稜の面取りを行うことで回避することができる.

\section{4 仮想物体の可動方向成分導出}

仮想環境の可動モデルと環境モデルの干渉時における，可動 モデルの動作可能成分を得るために, 速度に関する拘束条件式 （拘束不等式）を求める. 可動モデルの基準点速度を作業空間に 固定した絶対座標系において, 並進速度 $\dot{X}$, 角速度 $\omega$ として表 す.一点接触の際の拘束条件式は, 基準点から接触点への距離べ クトルを $(x, y, z)^{T}$, 接触点における法線ベクトルを $n=\left(n_{x}\right.$, $\left.n_{y}, n_{z}\right)^{T}$ とすると,

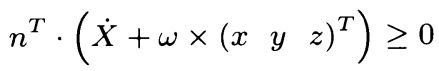

であり，これを整理すると，

$$
\begin{aligned}
& {\left[\begin{array}{lll}
n_{x} & n_{y} & n_{z}\left(-n_{y} z+n_{z} y\right)\left(n_{x} z-n_{z} x\right)\left(-n_{x} y+n_{y} x\right)
\end{array}\right]} \\
& \text {. }\left[\begin{array}{l}
\dot{X} \\
\omega
\end{array}\right] \geq 0
\end{aligned}
$$

と表される。一般に接触点が $n$ 個ある場合の拘束条件式は式 （2）をならべた連立不等式となり,

$$
C\left(\begin{array}{c}
\dot{X} \\
\omega
\end{array}\right) \geq 0
$$

という速度についての連立線形不等式で表される. $C: n \times 6$ は 係数行列で， $n$ は等価な拘束点（接触点）の数である.この係 数行列は干渉点での外向き法線べクトルと, 接触点座標值とで つくられる.

この不等式の解は，凸多面錐になることが知られている．等号 を成立させる解はすべての接触状態を維持する速度であり, 不 等号を成立させる解は，いずれかの接触点を離脱させる速度に 対応する [16]. 可動モデルの動作可能成分は，モデルの速度を この凸多面錐に正射影することにより, 求めることができる.

\section{4. 仮想環境操作システム}

ロボットを遠隔操作するための仮想環境操作システムを構築 し実験を行った。

\section{1 システム構成}

システムは以下のように構成される.

（1）仮想環境が格納されている PC.

(2) 仮想環境の表示・操作を行う GUI の構築と, 可動モデ ルと環境モデル同士の干渉チェックシミュレーションを行 う PC/WindowsNT4.0 (CPU:Pentium $128 \mathrm{Mhz}$, Memory : $96 \mathrm{Mb})$.

（3）マスターアームの制御を担当するボードコンピュータ 68040/VxWorks.

仮想環境が格納されているコンピュータにはWebサーバが起 動されており，Web ブラウザからアクセスしてオペレーション 用の PC にダウンロードすることで GUI が構築される，GUI の構成は以下のようになっている.

（1）仮想環境グラフィクス表示のための VRML プラグイン (SGI 社製 CosmoPlayer2.0). 


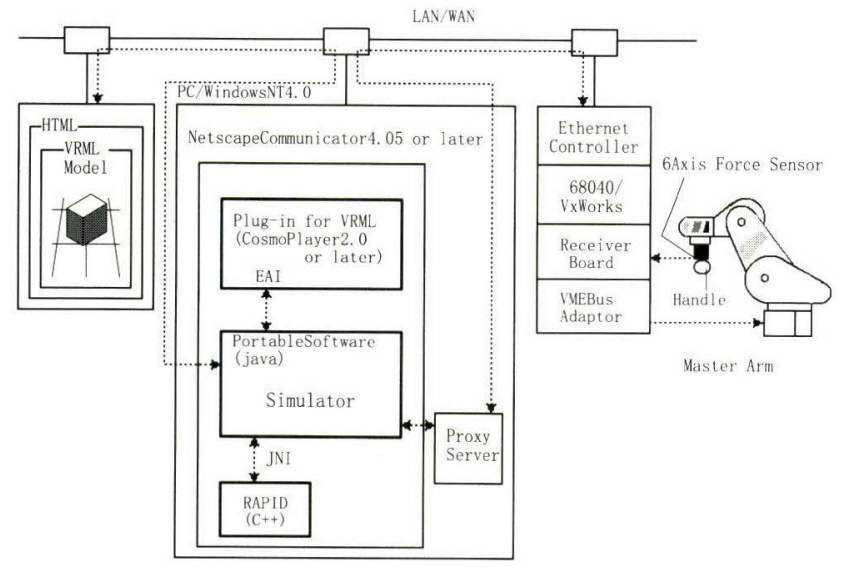

Fig. 5 Construction of system

（2）仮想環境中のモデルの操作，マスターアームとの通信を行 う Java（サン・マイクロシステムズ・インコーポレーテッ ド商標登録) アプレット.

（3）干渉チェックを行うモジュール.

Java アプレットから仮想環境中のモデルを動かすためには, VRML 世界を操作するための Java のライブラリである EAI (External Authoring Interface) を使用し, Javaアプレット から干渉チェックモジュールを動作させるためには，Java 言語 から他のプログラミング言語のモジュールを呼び出す機能であ る JNI（Java Native Interface）を使用した。また，Javaアプ レットは自分自身のダウンロード元以外との HTTPによる通信 を禁止する仕様のため, ProxyServer を経由してマスターアー ムとの通信を行う。本実験では, 仮想環境が格納される PC と, ユーザインタフェースを構築する $\mathrm{PC}$ は同一の PC とした。

マスターアームの手先には 6 軸力覚センサ (Jr3 社製) が取 り付けられており，さらにその先にユーザが操作するハンドル が取り付けられている (Fig. 5).

ボードコンピュータである 68040/VxWorks は, 力覚センサ から読み取った值に比例した值を，モデルの指示動作ベクトル としてシミュレータに渡す。そして, 干渉チエック㖟に得られ た值をマスターアームの手先の速度として受け取り,メモリに その值を書き込んでマスターアームを動作させる。

\section{2 処理の流れ}

本システムにおけるユーザの動作に伴う, システム処理の流 れの概略を機能線図 Fig. 6 を使って説明する. 初めに, WWW ブラウザ上に提示した仮想環境中にある任意のモデルをマウス で選択し，その情報をシミュレータに送る。次に，シミュレー夕 中の RAPID はモデルが記述されているVRML ファイルの構 文解析を行い, 可動モデル, 環境モデル共に, 先に述べたTree 構築を行う。この準備の後, マスターアームのハンドルに加え た力に比例する指示動作ベクトルが干渉検出モジュールに送ら れ (力入力), 可動モデルと環境モデルが接触していない場合 は，指示動作ベクトルがそのまま可動べクトルとして出力され る。それらが接触している場合は，3章に述べた方法で動作可 能成分が導出され，それが可動ベクトルとして出力される（動 作出力）。また同時に仮想環境中の可動モデルの位置変更が可動

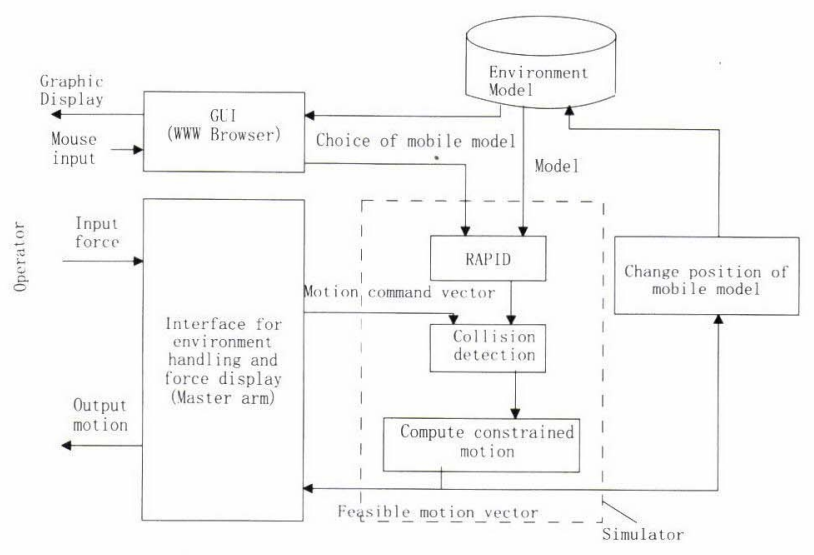

Fig. 6 Diagram of system functions

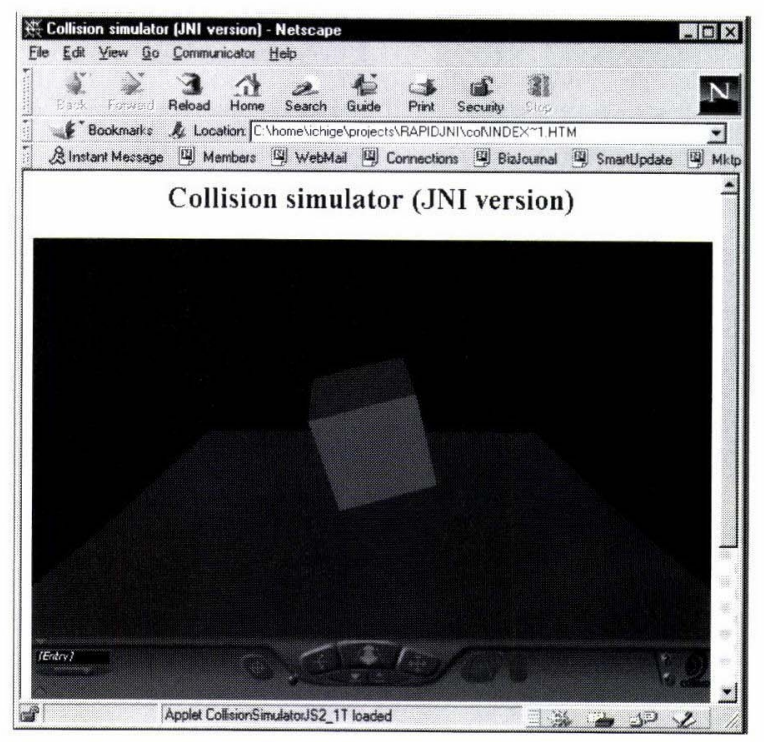

Fig. 7 Example of a basic experiment

ベクトルを用いて行われ，環境モデルが更新される（モデル更 新).このように力入力, 動作出力, モデル更新のサイクルが繰 り返されることで，干渉検出を行いながら仮想環境中の物体を 操作できる.

\section{5. 実験}

基礎実験として仮想角柱と仮想床で構成される環境での実験 例を示す (Fig. 7).

角柱が床に接触する際には，しっかりとした力感覚を得られ， 表面を滑らかに滑ることも可能である。才ペレータがハンドル に力を加えてから拘束計算を行い, ロボットアームの手先を動 かすまでの一連のループにかかる時間を Fig. 8 に示す. 実行 時間は括弧無しが基礎実験，括弧付きが後に述べる応用実験の データである.

基礎実験時に，可動モデルの角柱を床に押し付けてから環境 モデルの床にそって動かした際の，仮想環境グラフィクス表示 部をFig. 9 に示す. 可動モデルの箱が画面右上から環境モデル の床に押し付けられ，床上を滑って行く様子である。 


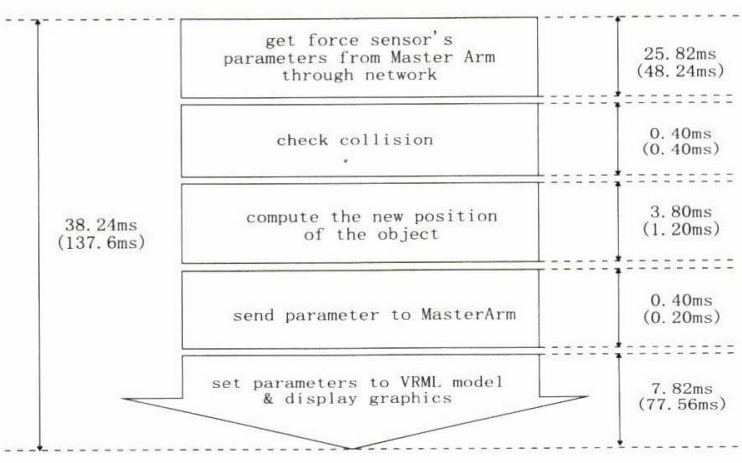

Fig. 8 Execution time
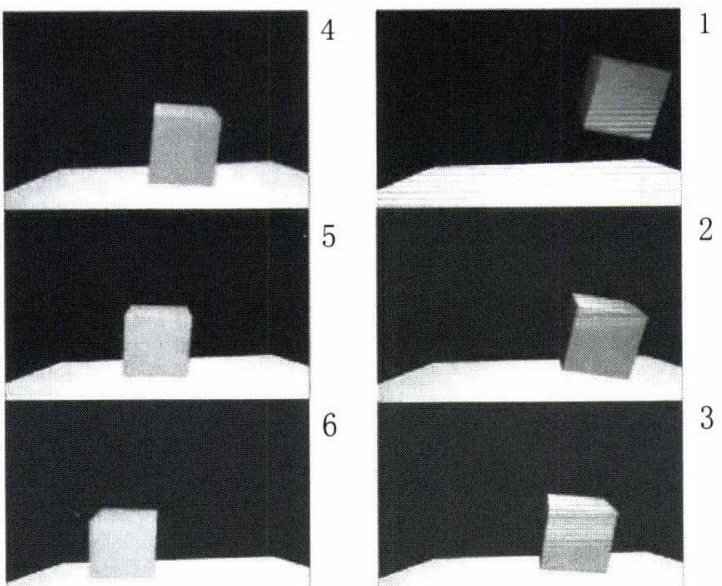

Fig. 9 Collision test on a WWW browser

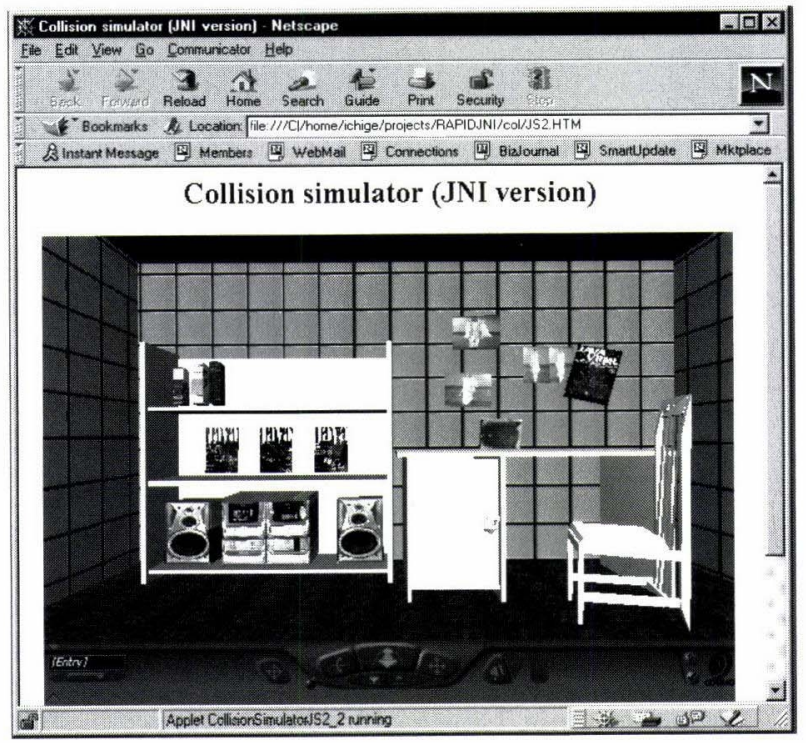

Fig. 10 The virtual room used in the experiment

次に応用実験例を示す。このシステムの応用として，例えば 家の中で働くロボットなどが考えられることから，この例を想 定した仮想環境における実験例を Fig. 10 示す.

この仮想環境には部屋の床や壁, 机, 椅子, 本棚, 数冊の雑 誌, ステレオ機器などのモデルが存在し, これらのモデルの中
で, 椅子, 本, 雑誌, ステレオ機器は可動モデルとした。 オペ レータはマウスのクリック動作で選択し, 可動モデルを動かす ことができる。

この実験での実行時間を Fig. 8 の括弧内に示す.応用実験例 では, 実行時間に $140[\mathrm{~ms}]$ 程度かかる. 力を加えるタイミング に対してモデルとアームの動作の反応が遅く, 快適な操作性が 得られるとは言い難いが, 干渉した感覚はシャープに得られる. 実行時間の大部分は画面の描画処理 $(77.56[\mathrm{~ms}])$ と通信時間 (48.24 [ms]）であり，干渉判定にかかる時間は $0.40[\mathrm{~ms}]$ と基 礎実験と変わりない。これはポリゴン数が増えても, 干渉に関 係する可動モデルと環境モデルの接触計算のみを行い, 干涉し ていない環境モデル間との接触計算は行わないためである. し たがって本実験以降の計算機性能の向上を考えると, この問題 はすぐ解消されることが予想できる.

\section{6. おわりに}

本研究では，ロボットのオフライン遠隔操作教示システムへ の応用を想定し，視覚に加え力覚提示を可能にすることで優れ た操作性をもたらす仮想環境操作システムを構築した。このシ ステムは標準的ヒューマンインターフェース, 標準通信プロト コル，ネットワーク可搬言語を用いている。また，マスタデバイ スとして標準的位置制御型ロボットアームを使用し，仮想環境 中の可動モデルの拘束運動をダイレクトにロボット（マスター） アームに返すシステムを構築, 実験を行った。

実験によって, 本研究で提案した拘束運動を導出するアルゴ リズムを組み込んだ全体システムが, 適切に機能することが確 認できた.

今後の課題としては，ロボットアーム以外の入出力デバイス の適用 [17], 実環境に存在するロボットの操作等が考えられる.

また，現在CORBA を通信に，JAVA を開発プログラミング 言語に用いた，分散オブジェクトシステムの開発が急速に進ん でいる、今回のようなシステム構成から CORBAを用いた分散 オブジェクトにすることで，さらにネットワークに分散したロ ボットの遠隔操作システムを容易に構築できる.

\section{参 考 文 献}

[1] 比留川, 他：“ワールドワイドロボティクスの提案—その 1：VRML を用いたオフライン遠隔操作システム”, 第 2 回ロボティクスシンポ ジア予稿集, pp.108-113, 1996.

[2] 原, 比留川, 他: “ワールドワイドロボティクスの提案—その 2: WWW ブラウザを用いた遠隔操作環境の構築”, 第 2 回ロボティクスシンポ ジア予稿集, pp.114-119, 1996.

[3] The Telegarden: http://www.usc.edu/dept/garden/

[4] R. Siegwart, C. Wannaz, P. Garcia and R. Blank: "Guiding Mobile Robots through the Web," Workshop Proceeding of the 1998 IEEE/RSJ International Conference on Intelligent and Systems (IROS), pp.1-6, 1998.

[5] P. Saucy and F. Mondada: "KhepOnTheWeb: One Year of Access to a Mobile Robot on the Internet," Workshop Proceeding of the 1998 IEEE/RSJ International Conference on Intelligent and Systems (IROS), pp.23-29, 1998.

[6] R. Simmons: "Xavier: An Autonomous Mobile Robot on the Web," Workshop Proceeding of the 1998 IEEE/RSJ International Conference on Intelligent and Systems (IROS), pp.43-47, 1998. 
[ 7 ] M. Stein: "Painting on the World Wide Web: The PumaPaint Project," Workshop Proceeding of the 1998 IEEE/RSJ International Conference on Intelligent and Systems (IROS), pp.37-42, 1998.

[8] 福井, 下条：“力覚をフィードバックする操作デバイスによる仮想形状 のなぞり動作”，電子情報通信学会論文誌，D-II，vol.J74-D, no.8， pp.1052-1059, 1991.

[9] 木野, 雨海, 高瀬：“力主導型マスターアームを用いた力呈示による 仮想物体操作”, 電気学会研究会資料, SC-97-30, pp.73-79, 1997.

[10] 木南, 尹, 妻木, 内山：“6 自由度型小型ハプティックデバイスの評価 と仮想剛体間の接触実験”，第 17 回日本ロボット学会学術講演会予 稿集, pp.415-416, 1999 .

[11] 吉川，横小路，他：“動特性を考慮した仮想物体操作感の実現”，日本 ロボット学会誌, vol.11, no.8, pp.1236-1243, 1993.

[12] 吉川, 川井：“並列バネ駆動による仮想物体表面の弾性係数向上につ
いて”, 第 17 回日本ロボット学会学術講演会予稿集, pp.397-398, 1999.

[13] 坂口，福住，古荘：“ER ブレーキを用いたパッシブ型力覚提示シス テムに関する基礎研究”, 第 17 回日本ロボット学会学術講演会予稿 集, pp.393-394, 1999.

[14] 神徳，高宗，他：“コンフィギュレーション空間を利用した仮想空間 における拘束力計算法”, 計測自動制御学会論文集, vol.33, no.10, pp.1026-1034, 1997.

[15] http://www.cs.unc.edu/geom/OBB/OBBT.html

[16] 比留川：“組立作業過程における拘束の表現と解析”, 日本ロボット学 会誌, vol.11, no.2, pp.192-200, 1993.

[17] 上田, 高瀬, 比留川：“3 自由度フォースフィードバック・マウスの試 作”, 第 17 回日本ロボット学会学術講演会予稿集, vol.3, pp.827-828, 1999

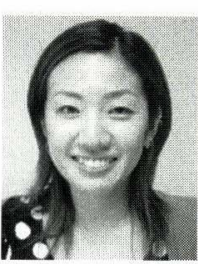

\section{市毛由希子（Yukiko Ichige）}

1974 年 9 月 3 日生. 1999 年電気通信大学大学院情 報システム学研究科博士前期課程修了. 同年 (株) 日立製作所機械研究所に入社。医療福祉ロボットの 研究に従事.

(日本ロボット学会正会員)

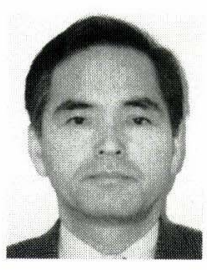

\section{高瀬國克（Kunikatsu Takase）}

1944 年 3 月 26 日生. 1970 年東京大学大学院工学 系研究科修士課程修了。同年電気試験所 (現：産業 技術総合研究所）入所. 1994 年より電気通信大学 大学院情報システム学研究科教授. 工学博士.

(日本ロボット学会正会員)

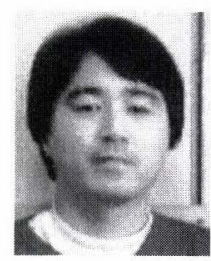

比留川博久 (Hirohisa Hirukawa)

1959 年 1 月 15 日生. 1987 年神戸大学大学院自然 科学研究科システム科学専攻博士課程修了. 同年電 子技術総合研究所（現：産業技術総合研究所）入所. 現在, 産業技術研究所知能システム研究部門ヒュー マノイド研究グループ. 知能ロボットの研究に従事. 学術博士.

(日本ロボット学会正会員) 